Скуратко T. М.

кандидат філологічних наук, асистент кафедри історії української літератури Тернопільського національного педагогічного університету імені Володимира Гнатюка

\title{
МИСТЕЦТВО МОДЕЛЮВАННЯ ЧАСУ Й ПРОСТОРУ В ПОЕМАХ ІВАНА ДРАЧА
}

У статті досліджено хронотопний світ у поемах Івана Драча, простежено розвиток драматизованої авторської думки, окреслено філософсько-психологічне підгрунтя поемної творчості мития, вивчено впливи літературних традичій (Т. Шевченко, I. Франко, Леся Украӥнка, П. Тичина, М. Рильський, М. Бажан) на формування літературного світогляду та стилю І. Драча. Значна увага приділяється суб 'єктній організації авторської свідомості в ліро-епосі поета.

Ключові слова: жанр, поема, ліро-епос, хронотоп, часо-простір, епічність, драматизм, художній стиль, образ, сюжет, поет, ліричний герой.

В статье исследован хронотопный мир в поэмах Ивана Драча, прослежено развитие драматизированной авторской мысли, очерчень фрилософскопсихологические основы поэмного творчества писателя, изучены влияния литературных традиций (Т. Шевченко, И. Франко, Леся Украинка, П. Тычина, М. Рыльский, Н. Бажан) на формирование литературного мировоззрения и стиля И. Драча. Значительное внимание уделяется субъектной организации авторского сознания в лиро-эпосе поэта.

Ключевые слова: жанр, поэма, лиро-эпос, хронотоп, временное пространство, эпичность, драматизм, художественный стиль, образ, сюжет, поэт, лирический герой.

The article investigates space and time correlation (chronotop) in the poems by Ivan Drach, examines the dramatization of the poet's thinking, and outlines philosophical and psychological background of his poetic writings. The article also analyzes the influence of literary canon and tradition (T. Shevchenko, I. Franko, Lessya Ukrainka, P. Tychyna, M. Rylskuy, M. Bazhan) on Ivan Drach's literary style and outlook. The author's conceptual frame and structure of subjective consciousness as revealed in his poems are considered in the article.

Key-words: genre, poem, chronotop, space and time correlation, epic poetry, dramatization, literary style, plot, image, poet, lyrical hero. 
Дослідники творчості І. Драча відмовилися від трактування ii як екстравагантного феномена. Безповоротно минули ті часи, коли його доробок не сприймався деякими рецепієнтами, а сам поет зазнавав гострих і несправедливих звинувачень з боку тенденційної критики, що спрощено інтерпретувала художній дискурс поета. Відтак інтерес сучасних дослідників до його творів та неповторної стильової палітри не спадає, зумовлюючи появу нових розвідок та студій. Відвертий інтелектуалізм й імпліцитна фольклорність, розкрилля творчої фантазії і по-драматичному концентровані художні образи, метафоричність мислення і драматизм характерні ознаки творчої манери І. Драча.

Поемам митця властиве осмислення долі великої кількості персонажів із широким соціально-історичним часопростором. Інтерпретація простору у поета пов'язана з розкриттям конкретного задуму, - це простір, який уміє розмовляти, дихати, відчувати, співпереживати. В основному митець звертається до внутрішнього простору - простору думок, переживань, емоцій героїв. Характерним для Драчевих персонажів $є$ перебування у «міжчасів’ї», у «безчассі», у такому часовому пласті, який розташований «між» протилежними часовими координатами - минулим та майбутнім, що виявляється вже у метанаративі заголовків, які у поета маркують головну думку твору, що моделюється у вигляді метафоричного узагальнення. Заголовок є, по суті, пафосним ядром, своєрідним центром, концепцією Драчевих творів. Так, у «Зорі і смерті Пабло Неруди» поет - уособлення думки про свободу і несвободу митця; у «Соловейко-Сольвейг» митець - не так конкретна людина, скільки метафоричне узагальнення долі митця; в «Думі про Вчителя» - символічне втілення ідеї поєднання в образі Вчителя мужності, непримиренності в боротьбі зі злом і безмежної доброти; «Ніж у Сонці» уособлює моральну катастрофу, яка нависла над людством. Незвичайною є архітектоніка поем митця, яка складається зі своєрідного метафоричного обрамлення та основної частини, в яку вставлені епізоди буття персонажів, що мають складну 
побудову різних часових відрізків. Так, основою структури драматичної поеми «Дума про Вчителя» $є$ часовий і просторовий синтез. Потрійна експозиція («Слово до читача», «Слово до режисера», «Слово до редактора»), яка своєрідно обрамлює твір, підводить нас до основних подій поеми, що відбуваються у десяти картинах 3 прологом та епілогом.

У поемі можна виявити декілька фабульних площин: дія в обрамленні; роздуми про долю В. Сухомлинського; дія в кабінеті Ученої Установи; зустріч з Бляхою-Мухою; інформація про подальшу долю Вчителя; дія в Павлищанській школі; Верховний Педагогічний Суд. Основою структури твору є часовий і просторовий синтез. Контрастно поєднуються локальні простори: рамковий простір - звернення до читача, режесера, редактора, і простір, в якому розкривається трагедія видатного педагога В. Сухомлинського.

Отже, дія відбувається у реальному часі, що збігається з роками життя і діяльності персонажа твору, однак для створення цілісної картини поет вдається до аналепсисів і пролепсисів; конкретний теперішній часопростір виступає в обрамленні як локально обмежений і візуально закритий. Локальний теперішній хронотоп вимірюється лише певним періодом 3 життя В. Сухомлинського, тоді коли загалом твір охоплює значний соціально-історичний хронотоп. Характерно, що соціально-історичний часопростір не створюється окремо, він хронологічно неупорядкований, виступає не як тло подій, а чинник, що структурує художній світ у цілісність.

Драматичний конфлікт, який становить собою фабульносюжетний час, у поемах І. Драча суттєво відрізняється від конфлікту в суто драматичних творах, зокрема трагедії чи трагікомедії; на характер зіткнення дійових осіб у драматичній поемі впливає також ліричний струмінь, що переважає в ліричній поемі. Втручання автора у конфлікт характерів надає йому рис конфлікту ідей, який полягає в тому, що він зумовлює постій атмосферу роздвоєності, бінарну цілісність широкого епічного полотна. 
Конфлікт ідей $є$ визначальною особливістю драматичних поем I. Драча. Деякі критики, зокрема Б. Горин [Горин 1996: 120], М. Ільницький [Ільницький 1986: 150], М. Рябчук [Рябчук 1981: 163], А. Янченко [Янченко 1980: 16], не приймають такого конфлікту, вважаючи його надто схематичним через надмірне використання публіцистичних засобів, тобто виступають проти художньої дифузії жанру. Однак не слід забувати, що драматична поема є жанром синтетичним і штучне «прив'язування» іiї до певних суто родових ознак призводить до однобічної оцінки твору.

Б. Олійник, вивчаючи генеалогію Драчевої ліро-епіки, цілком справедливо вбачає іiі корені у творчості Лесі Українки [Олійник 1973: 140]. Доречно з цього приводу навести цікаве зізнання самого І. Драча: «У творчості Лесі Українки мене більше приваблює драма, ніж лірика. У драмах вона - поетеса світового рангу, наявність такого автора могла б зробити честь найрозвиненішій національній культурі» [Драч 1977: 34]. Саме Леся Українка $є$ чи не першою в українській літературі письменницею, яка сміливо виводить на театральний поміст ідеї, яким належало двобоєм утверджувати правду.

Відоме твердження, що «Лісова пісня» є феєричним увічненням боротьби добра і зла й оспівуванням апофеозу перемоги природного начала, втіленого в символічному образі красуні лісів Мавки. У драматичній поемі Лесі Українки «Одержима» пафос боротьби і буденність всепрощенства також виступають ідеямиантиподами. Подібні «оживлені» конфлікти ідей зустрічаємо в інших творах Лесі Українки, а також у іï наступників I. Кочерги, Л. Первомайського, О. Левади та І. Драча.

Отже, І. Драч активно спирається на традиції, шукаючи нових акцентів в оголеному, здавалось би, конфлікті, розвиває його та надає синтетичних рис.

Важливо з'ясувати основні риси конфлікту ідей загалом у драматичних поемах I. Драча. На нашу думку, це - високий ступінь абстрагованості від конкретних подій чи, більше того, вчинків окремих людей. 3 цією метою, наприклад, автор постійно іменує 
Пабло Неруду поетом, В. Сухомлинського - Вчителем, Марину Турчин - скульптором. Таким чином, він, спираючись на конфліктну особистість, шукає в ній рис, які визначають ії індивідуальне обличчя, і разом з тим художньо досліджує іiі типовий характер. Пабло Неруда - то не лише чилійський поет, а ідеал народного співця. В. Сухомлинський - не лише директор Павлищанської школи, це символ досвіду педагогіки всіх віків. Слід наголосити, що І. Драч майже не використовувує зовнішніх ефектів. Може виникнути контрзапитання: а чи варто вважати «зовнішнім ефектом» корабель 3 його «вільним принципом» («Зоря і смерть Пабло Неруди»). На перший погляд, він справді, здавався б, особливо зі сцени, оригінальним атрибутом оформлення. Але такий підхід серйозно збіднює якісне, повноцінне розуміння твору загалом. По-перше, корабель - це символ мрії, хоч і не здійсненої. Згадаймо хоча «Парус» М. Лермонтова, «Майстер корабля» Ю. Яновського чи фінал повісті В. Катаєва «Белеет парус одинокий».

По-перше, зовсім по-іншому сприймаються після цих аналогій мрії Поета у драмі І. Драча про затишок, спокій, мрії людини знедоленої, втомленої постійними переслідуваннями і поневіряннями: - Я капітан, але судно моє затонуло. / А ти заходь, друже, подруго, товаришу, / заходь на мій корабель, / а ти побудь у моєму домі, I побудь, ти не лякайся оцих громил, / які тимчасово там порядкують, у моїй капітанській вітальні... [Драч 2006: 343]. Цим довірливо-інтимним відтінком у діалозі з глядачем драматург, безперечно, лише увиразнює конфлікт, надаючи йому більшої гостроти і трагічності.

По-друге, корабель - символ всієї творчості П. Неруди. Мариністська тематика $\epsilon$ провідною в його поезії. Досить навести назви збірок, щоб пересвідчитись у цьому: «Море і дзвони», «Великий океан», «Плавання і повернення», «Вірші Капітана», «Меморіал Чорного острова». Корабель - улюблений образ П. Неруди. Він навіть любив називати себе Капітаном. Та й сам I. Драч не заперечує запозичення цього образу-символу поеми 3 творчості 
П. Неруди: «Такий цей корабель постає зі спогадів сучасників, очевидиів, друзів і наклепників» [Драч 2006: 201]. Більше того, автор заповнює сцену специфічним реквізитом - улюбленими речами Поета, пов’язуючи тим самим образ корабля з біографією чилійського митця. Відомо, як по-особливому, навіть меланхолійно ставився П. Неруда до різноманітних дрібничок домашнього побуту.

Проте оригінальність I. Драча не в реквізитному антуражі, а в тому, якого значення він надає тим речам, які знаходяться на сцені. Усі вони збільшених, навіть гігантських розмірів: Великий Дерев'яний Черевик, Великий Чорний Дерев'яний Ключ, Величезне колесо старої гарби, Пісочний Годинник, Величезний завбільшки з людину, Великий барабан, Величезний глобус старовинної роботи [Драч 2006: 334]. Прирівнюючи речі до людей (характерно, що на нижній палубі, де вони розміщені, діють переважно негативні персонажі), І. Драч тим самим прирівнює людців Ареляно, Ромео до речей на зразок Величезного Вуха. Таким чином, через гіперболу щодо речей автор застосовує літоту щодо людей (подібний прийом зустрічаємо у казці братів Грімм «Хлопчик-мізинчик»).

Окрім того, всі предмети у поемі функціонують самі по собі. У критиці ця деталь чомусь обійдена мовчанням, а поет, між іншим, хотів звернути на це увагу читача, навіть виділивши слова «САМІ ПО СОБІ» особливим шрифтом. Звичайно ж, і тут можна знайти типологічну спільність з творчістю Пабло Неруди: ... nрошли они жизнью моей, / жили вместе со мной / и этапь настолько живыми, / что, наверное, прожили / жизни моей половину / и, наверное, смертью моей / наполовину умрут [Неруда 1978: 141], пише він у «Оді речам». Мабуть, це зізнання і лягло в основу самочинності мертвих предметів, що через якісь приховані внутрішні зв'язки підкреслює прагнення П. Неруди до духовної свободи. Отже, деталі реквізиту мають не тільки фонове, а й смислове наповнення при творенні конфлікту, увиразнюють його.

I. Драч, спираючись на традиції вертепної драми, поділяє корабель на дві палуби - верхню і нижню. На верхній палубі дія $є$ 
цілком ретроспективною і здебільшого документальною. Головною дійовою особою на ній є Пабло Неруда. На верхній палубі перед нашими очима проходять найпам'ятніші сторінки життя великого чилійського співця, дія, що відбувається тут, є, по суті, втіленням його високих ідеалів. На нижній палубі діють вороги Поета - капітан Ареляно і три Ромео, які ведуть принизливий допит Джульєтти, що символізує вічно живу красу життя, вітаїзм пізнання.

Такий «розподіл» дії грунтується на забутих традиціях народного лялькового театру Середньовіччя. Згадаймо «триповерховий» принцип постановки «шкільних» п'єс, де на верхньому ярусі діяли боги, ангели, тобто позитивне начало у житті, а на нижньому демонічні сили (тобто негативне начало), що намагались спокусити простолюдинів. Таке «спокушування» в поемі І. Драча особливо увиразнюється у зв'язку з використанням образів Ромео і Джульєтти. Переосмислення цих образів особливо ефективне через те, що характер «спокушування» за допомогою електричного струму діаметрально протилежне у всіх відношеннях до того ідилічного кохання, яке склалося між героями трагедії В. Шекспіра. А оскільки конфлікт у драмі І. Драча відображає «драму ідей», то й мета «спокушування» відрізняється від тої, яку ставили перед собою демонічні сили у середньовічному вертепі. I тут знову присутність специфічних деталей: катування Джульєтти автор називає дослідженням «червоної Джулії». Нарешті, слід відзначити, що Джульєтта ще надто неосвічена і тому нагадує середньовічних простолюдинів, які були безпорадними перед вищими силами.

Цікавим є те, що автор «примушує» героїв верхньої і нижньої палуб вступати у діалог між собою, в якому ще більше виявляється ницість таких персонажів, як Критик, який вміє лиш цинічно заявити: Пабло Неруда поетом був / до книжки «Іспанія в серизі». / Нею він вдарив / у серие власній поезії [Драч 2006: 350], або задавати Поетові наївні питання: $A$ чому в «Оді Федеріко...»ви кажете, / щуо тепер через Лорку фарбують / в блакитний колір лікарні? [Драч 2006: 348]. 
Нарешті, «розподіл» дії на двох палубах має і суто практичні переваги, бо робить ії розгортання динамічнішим і конденсованішим.

Повертаючись до образу корабля у драматичній поемі І. Драча, слід зазначити, що він уособлює прогрес, про який мріяв П. Неруда. Згадаймо хоча б його вірш «Привид на борту вантажного судна», де у високохудожніх образах-символах (корабель, океан, привид) показується своєрідне пробудження активності: Внезапно вскипает вода за бортом; / волны топочут, /будто просится призрачный конь / и бьет в солёную воду копыта. / И снова топот захлебывается волной. / И в каютах остаётся оно только время:/недвижимое, внятное, словно большая беда [Неруда 1978: 9].

У І. Драча аналогічне значення образу корабля виявляється в тому, що цей образ впливає на капітана Ареляно, доводячи того до божевільного страху перед ним. У цьому плані образ корабля зближується 3 іншим символом - океаном. У шостому «зауваженні 3 приводу дії» I. Драч зазначає: «... весь час дихає океан, то лащчиться, то тяжко зітхає, то розкотисто жене хвилі, то бурунить. Постійне нагадування про себе. Океанське» [Драч 2006: 335].

Порівняймо це зауваження з рядками вірша П. Неруди «Великий океан» (цикл «Пісні для Всіх»): Это дыхание твое поднимает и опускает струистый покров, ткань из литых и литучих лучей. Вся обнаженная кожа земли полировалось твоими волнами. Все сещество твое полно собой [Неруда 1978: 111, 331; переклад М. Самаєва].

Цікавим $є$ зіставлення океану 3 калюжами: «B калюжах важко кораблю ходити, Лаштуймося на океан» [Драч 2006: 333], бо воно неодмінно викликає асоціації з нерудівськими кораблем, що долає океанічні обшири, і корабликом у пляшці [Неруда 1978: 11].

Привертає увагу і запозичене порівняння Чилі з балконом (воно, до речі, зустрічається і в «Президенті» В. Земляка). Для Пабло - його Чилі - це балкон, півострів, одним боком зв'язаний 3 гнітючою віделівською, а потім піночетівською дійсністю і омитий освіжаючим вирієм великих мрій поета. 
Так чи інакше кожен 3 цих атрибутів чи епізодів служить єдиній меті: вирізнюванню 3-поміж метушливої зміни подій основної ідеї, роздвоєної на два суперечливі начала - добро і зло. Саме у цьому вимірі, у «драмі ідей», у філософському спрямуванні конфлікту, що лише увиразнює його соціальну суть, А. Янченко визначає «конфлікт між Пабло Нерудою і реакційними силами чилійської вояччини» [Янченко 1980:16].

Таким чином, драматичний конфлікт у творах I. Драча умовний, символічний і колажний. Він $є$ не схемою, а живим втіленням конкретних характерів передусім у зв’язку з ліричною наснаженістю цих творів. Автор моделює зовнішні та внутрішні конфлікти, багатогранно змальовує образи, характери протагоністів. Поеми І. Драча наповнені філософічністю, порушують вічні онтологічні питання буття, життя і смерті, вірності і зради, правди і кривди. Своєю філософічністю драма I. Драча зближується 3 «Фаустом» Й.В. Гете.

Отже, поеми I. Драча виникли завдяки поєднанню підвищеного інтересу до суспільних проблем (і не у вузькорегіональному, а у світовому масштабі) з утвердженням цінності, неповторності творчої особистості, яка має право на саморозкриття, збільшення до неї уваги і поваги. Епічний і ліричний план поеми взаємодоповнюють, посилюють один одного, через що відкриваються нові поетичні можливості жанру. В епічній площині його поем значно розширюється простір і час. Митець звертається до історії, минулого свого народу, творчого переосмислення сьогодення. Кожний факт є для поета відкритим у просторі та часі, і думка, відштовхуючись від нього, вільно ширяє, накреслюючи кола, накладаючись і перехрещуючись з іншою.

Упродовж творчої еволюції І. Драча спостерігаємо наскрізну домінанту, що так чи інакше проходить через усю творчість митця: це, передусім, фабульна цілісність соціально-історичного хронотопу поем митця, яка складається із персонажних мініатюр, які додаються, доповнюються, уточнюються, увиразнюються колаж- 
ним принципом, що є довільним зіставленням автономних за змістом хронотопних фрагментів. У поетичному епосі письменник застосовує такі жанрові прийоми, як часові зміщення: пролепсиси (повернення в минуле) та аналепсиси (забігання в майбутнє), що розширюють семантичне поле поем, апробуючи модерні наративні прийоми відтворення світу: майстерно оперуючи ними, автор моделює майбутнє героїв, за допомогою яких повніше окреслюються характери героїв, їх минуле, сучасне і майбутнє.

\section{БІБЛІОГРАФІЯ}

Гнатюк 1972 - Гнатюк М. П. Поема як літературний вид / Гнатюк М. П. - К.: Дніпро, 1972. - 112 с.

Горин 1996 - Горин Б. Рідкісне обдарування [І. Драч] / Б. Горин // Дзвін. - 1996. № 10-12. - С. 117-122.

Дем'янівська 1984 - Дем'янівська Л. С. Українська драматична поема: Проблематика, жанрова своєрідність / Дем'янівська Л. С. - К.: Вища школа, Голов. видво, 1984. - 160 с.

Драч 1977 - Драч I. Ф. Наблизитися до серця читача: Запитання німецького літературознавця і відповіді поета / І. Драч . // Укр. Мова і літ. в шк. - 1977. - № 9. C. 31-34.

Драч 2006 - Драч І. Ф. Поеми ; упорядкув. та післямова А. Ткаченка; передм. М. Жулинського / І. Драч - К. : Генеза, 2006. - 512 с.

Ільницький 1986 - Ільницький М. Іван Драч: нарис творчості / М. Ільницький. К. : Рад. письменник, 1986. - 221 с.

Копистянська 1997 - Копистянська Н. Аспекти функціонування простору, просторової деталі в художньому творі / Н. Копистянська // Молода нація. - К., 1997. - Вип. 5. - С. 172-173.

Копистянська 1993 - Копистянська Н. Х. Художній час як категорія порівняльної поетики / Н. Копистянська // Слов'янські літератури: матеріали до з'їзду славістів. - Вип. ХІ. - К., 1993. - С. 184-200.

ЛСД 2006 - Літературознавчий словник-довідник ; за ред. Р. Т. Гром’яка,

Ю. І. Коваліва, В. І. Теремка. - К. : ВЦ «Академія», 2006. - 752 С. (Nota Bene). Неруда 1978 - Неруда П. Сочинения: в 4 т. / П. Неруда. - М. : Худ. лит., 1978. - 612 с. Олійник 1973 - Олійник Б. І. До глибини джерел / Б. Олійник// Дніпро. - 1973. № 10. - С. 138-140.

Рябчук 1981 - Рябчук М. Парадокси дорожні і поетичні / М. Рябчук // Вітчизна. 1981. - № 7. - С. 78-81.

Янченко 1980 - Янченко А. Пабло Неруда в уяві і документах / А. Янченко // Літературна Україна. - 1980. - 1 серпня. - С. 16.

Стаття найшла 7 версня 2013 р. 